\author{
製 \\ 田 所 洋 三 \\ 日清製油 (株) 研究所（横浜市神奈川区干若町 1-3）
}

\section{Oilseed Processing}

\section{Yozo TADOKORO}

Research Laboratory, The Nisshin Oil Mills, Ltd. (1-3, Chiwaka-cho, Kanagawa-ku, Yokohama)

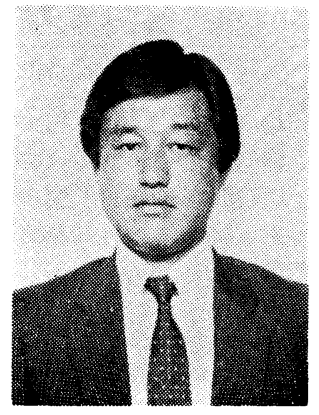

はじめに

製油産業をとりまく諸条件は相場, 油とかすのバラン 又等原料や市場面の基本的問題を残したまま，さらに世 界の政治・経済とのかかわりあいをいっそう強めてい る。技術面では，エレクトロニクス，バイオテクノロジ 一を中心とする華々しい新イノベーション時代といわれ る中で，製油そのものの革新的な技術開発は乏しいかも 知れない。しかしながらたとえばエネルギー問題, 環境 保全, 健康志向や食品の安全性, 新油脂源の開発, 現地 生産方式など，このおよそ 10 年の間にもめまぐるしい 変化があり, 製油もこれらの環境変化に技術進歩を通じ て対応してきている。従って製油技術は今後とも変革し て行くであろう。

本稿では油脂生産・消費の動向を眺めるとともに, 近 年著しく進展した省エネルギー，自動化ならびに二三の 興味ある技術開発について触れてみたい。

\section{1 油脂の生産・消費動向}

植物油, 動物油の用途別消費量の推移を表-1 に示 す。昭和 50 年の落ちこみ以降 51 年から 56 年に合計 量は年平均 $5 \%$ 程度伸び 245 万 $\mathrm{t}$ 亿達した。合計量の うち $75 \%$ 前後が食用で，植物油合計量のうち 85 87\% が食用である。植物油, 動物油の比率は昭和 40 年代が ほぼ 2 対 1 であったのに対し 50 年代にはいって 7 対 3 と植物油の割合が高まってきた。食用でのそれらの比率 は昭和 40 年代がほぼ 3 対 1 であったのに対し 50 年代 にはいって 4 対 1 と植物油の割合が高まった。

次に油脂消費の主体を占める食用油脂の年次別消費動 向を 表-2 に示す。合計量は昭和 $49 \sim 50$ 年の一時的後 退ののち 56 年まで順調に推移した。単体, その他加工 用に比べてマーガリン・ショートニングの伸び率の変動 は少なく，比較的安定した推移をたどっている。消費実
績の内訳は単体 $50 \%$ 強, マーガリン・ショートニング 約 20\%，その他加工用 $30 \%$ 弱となっている。マーガリ ン・ショートニングの割合は昭和 40 年代がほぼ $18 \%$ 台 であったのに対し 50 年代には 2 ポイント上昇し, 油脂 の付加価值が高められている。1人 $1 \mathrm{~d}$ 当たりの消費量 は昭和 55 年には $38 \mathrm{~g}$ に達し, 10 年前に比べて $10 \mathrm{~g}$ 強 も増加した。

厚生省の昭和 55 年度栄養摂取量調査によると（表-3） 日本人のエネルギー摂取における油脂エネルギーの割合 は 22\% に達し, いわゆる適正 PFC 熱量比 (P 12 13 $\%, F 20 \sim 30 \%$, C $68 \sim 57 \%$, 公衆衛生審議会, 昭和 54 年 8 月）からみて充分な状態にある。攝取脂肪の植物性 対動物性の比率は昭和 45 年当時おうそ 55 対 45 であ ったのが，50 年代には 48 対 52 となった。

植物油脂原料の品目別控油状況を 表-4 亿示す。全原 料に占的る国産原料の比率は漸減し 56 年 (見込み) に

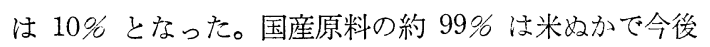
も增えない。輸入原料のうち大豆, なた悋の伸長が著し く, とらもろこしも増加した。綿実, サフラワー, ひま わり、コプラなど現地控油が進み油脂輸入が多くなっ た。輸入原料に占める大豆の割合は $70 \%$ に近く，なた ね㴔速に増加して $20 \%$ 程度となり大豆, なた㸚への 集中化が進んでいる。工場のスケールメリットを追求し て大型工場を稼湩させたこと, 原料の供給事情と需要条 件がマッチしたことによる1が，とくになたねについて はその品質改善努力2が見逃せない。

植物油かすの配合飼料用需要動向を 表-5 に示す。配 合飼料は昭和 51 年以降順調に伸び 2,200 万 $\mathrm{t}$ 亿達し たが，タンパク源としての大豆油かす及びなたね油かす の品質改良の結果配合飼料中に占める割合が増加したの で，配合飼料の伸び以上の伸長を示した。当今亩産の伸 びが鈍化し，ミールや油脂輸入による需給への影響が大 きいこともあり，搾油環境はむずかしい局面にある。 
表-1 油脂の用途別消費

(単位: 原油 $1,000 \mathrm{t}$ )

\begin{tabular}{|c|c|c|c|c|c|c|c|c|}
\hline \multicolumn{2}{|c|}{ 品目 年 次 } & 50 & 51 & 52 & 53 & 54 & 55 & 56 \\
\hline \multirow{2}{*}{ 食 } & 植 物 油 & $\begin{array}{l}(78.8) \\
1,004\end{array}$ & $\begin{array}{l}(82.3) \\
1,161\end{array}$ & $\begin{array}{l}(83.1) \\
1,215\end{array}$ & $\begin{array}{l}(81.4) \\
1,282\end{array}$ & $\begin{array}{l}(81.5) \\
1,376\end{array}$ & $\begin{array}{l}(80.9) \\
1,399\end{array}$ & $\begin{array}{l}(82.5) \\
1,537\end{array}$ \\
\hline & 動 物 油 & $\begin{array}{c}(21.2) \\
270\end{array}$ & $\begin{array}{c}(17.7) \\
249\end{array}$ & $\begin{array}{c}(16.1) \\
247\end{array}$ & $\begin{array}{c}(18.6) \\
292\end{array}$ & $\begin{array}{c}(18.5) \\
313\end{array}$ & $\begin{array}{c}(19.1) \\
330\end{array}$ & $\begin{array}{c}(17.5) \\
327\end{array}$ \\
\hline \multirow[t]{2}{*}{ 用 } & 計 & $\begin{array}{c}(100.0) \\
1,274\end{array}$ & $\begin{array}{c}(100.0) \\
1,410\end{array}$ & $\begin{array}{l}(100.0) \\
1,462\end{array}$ & $\begin{array}{l}(100.0) \\
1,574\end{array}$ & $\begin{array}{c}(100.0) \\
1,689\end{array}$ & $\begin{array}{l}(100.0) \\
1,729\end{array}$ & $\begin{array}{c}(100.0) \\
1,864\end{array}$ \\
\hline & 対前年比 (\%) & 96.0 & 110.7 & 103.7 & 107.7 & 107.3 & 102.4 & 107.8 \\
\hline \multirow{4}{*}{$\begin{array}{l}\text { 非 } \\
\text { 食 } \\
\text { 用 }\end{array}$} & 物 油 & 168 & 187 & 192 & 199 & 214 & 203 & 206 \\
\hline & 物 油 & 132 & 212 & 208 & 203 & 179 & 208 & 188 \\
\hline & 計 & 300 & 399 & 400 & 402 & 393 & 411 & 394 \\
\hline & 対前年比 $(\%)$ & 87.5 & 133.0 & 101.0 & 100.5 & 97.8 & 104.6 & 95.9 \\
\hline \multirow{4}{*}{$\begin{array}{l}\text { 輸 } \\
\text { 出 } \\
\text { 用 }\end{array}$} & 物 油 & 13 & 13 & 13 & 18 & 29 & 37 & 14 \\
\hline & 油 & 85 & 85 & 120 & 222 & 206 & 163 & 179 \\
\hline & 計 & 98 & 98 & 133 & 240 & 235 & 200 & 193 \\
\hline & 対前年比 (\%) & 64.1 & 100.0 & 135.7 & 180.5 & 97.9 & 85.1 & 96.5 \\
\hline \multirow{3}{*}{ 合 } & 植 物 油 & $\begin{array}{l}(70.9) \\
1,185\end{array}$ & $\begin{array}{l}(71.4) \\
1,361\end{array}$ & $\begin{array}{l}(71.2) \\
1,420\end{array}$ & $\begin{array}{l}(67.6) \\
1,499\end{array}$ & $\begin{array}{l}(69.9) \\
1,619\end{array}$ & $\begin{array}{l}(70.0) \\
1,639\end{array}$ & $\begin{array}{l}(71.7) \\
1,757\end{array}$ \\
\hline & 対前年比 $(\%)$ & 92.4 & 114.9 & 104.3 & 105.6 & 108.0 & 101.2 & 107.2 \\
\hline & 動 物 油 & $\begin{array}{c}(29.1) \\
487\end{array}$ & $\begin{array}{c}(28.6) \\
546\end{array}$ & $\begin{array}{c}(28.8) \\
575\end{array}$ & $\begin{array}{c}(32.4) \\
717\end{array}$ & $\begin{array}{c}(30.1) \\
698\end{array}$ & $\begin{array}{c}(30.0) \\
701\end{array}$ & $\begin{array}{c}(28.3) \\
694\end{array}$ \\
\hline \multirow{3}{*}{ 計 } & 対前年比 $(\%)$ & 90.0 & 112.1 & 105.3 & 124.7 & 97.4 & 100.4 & 99.0 \\
\hline & 計 & $\begin{array}{l}(100.0) \\
1,672\end{array}$ & $\begin{array}{l}(100.0) \\
1,907\end{array}$ & $\begin{array}{l}(100.0) \\
1,995\end{array}$ & $\begin{array}{l}(100.0) \\
2,216\end{array}$ & $\begin{array}{l}(100.0) \\
2,317\end{array}$ & $\begin{array}{l}(100.0) \\
2,340\end{array}$ & $\begin{array}{l}(100.0) \\
2,451\end{array}$ \\
\hline & 対前年比 (\%) & 91.7 & 114.1 & 104.6 & 111.1 & 104.6 & 101.0 & 104.7 \\
\hline
\end{tabular}

注）（）内は植物油, 動物油の製合 （資料）農林水産省食品油脂課

表-2 食用油脂の年次別消費

（単位：消費実績 1,000 t)

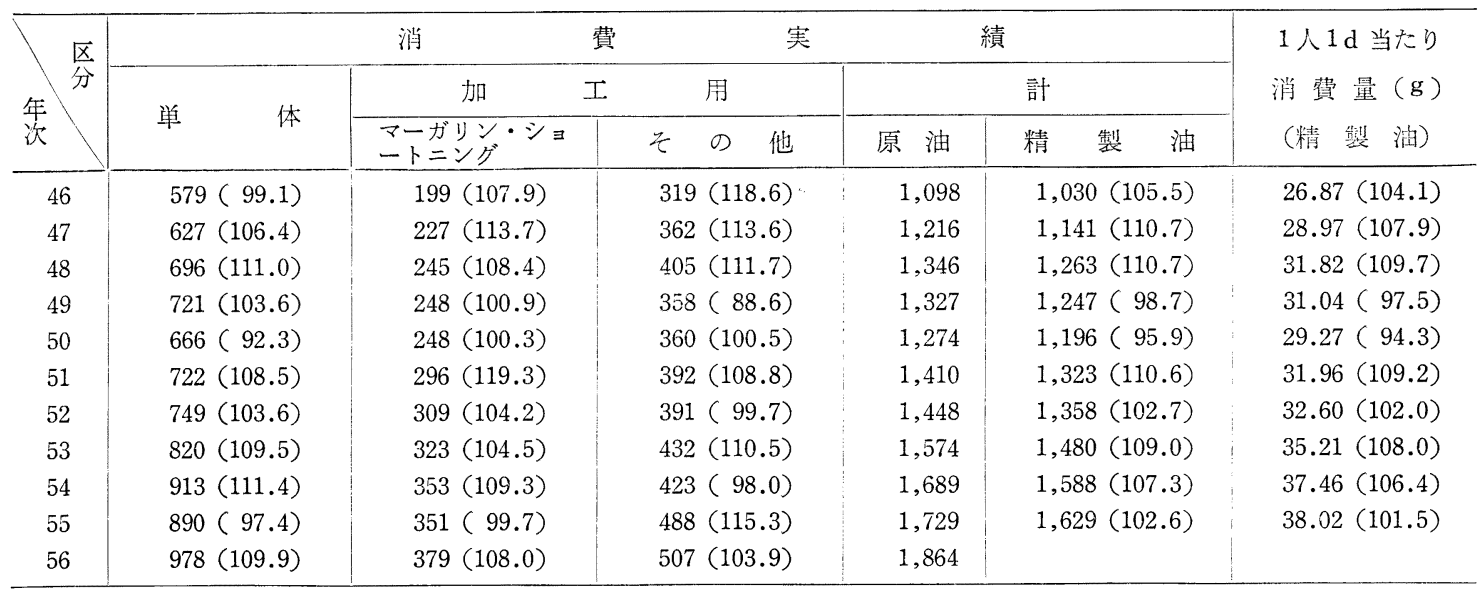

注）（）内は対前年比（\%) その他加工用はマヨネーズ用, 食用加工脂用, ラード等である。（資料）農林水産省食品油脂課 
表-3 栄養摂取量の年次推移

\begin{tabular}{|c|c|c|c|c|c|c|c|c|}
\hline & 40 年 & 45 年 & 50 年 & 51 年 & 52 年 & 53 年 & 54 年 & 55 年 \\
\hline エネルギ $-(\mathrm{kcal})$ & 2,184 & 2,210 & 2,188 & 2,159 & 2,149 & 2,167 & 2,113 & 2,084 \\
\hline タン パ ク 質 $(\mathrm{g})$ & 71.3 & 77.6 & 80.0 & 78.7 & 78.8 & 80.0 & 78.4 & 77.9 \\
\hline 岸 水 化 物 $(\mathrm{g})$ & 384 & 368 & 337 & 332 & 326 & 326 & 315 & 313 \\
\hline 脂，肪 $(\mathrm{g})$ & 36.0 & 46.5 & 52.0 & 52.4 & 53.8 & 54.7 & 54.8 & 52.4 \\
\hline $\begin{array}{l}\text { 点動物性脂肪の }(\%) \\
\text { 割合 }\end{array}$ & 39.7 & 44.9 & 52.7 & 51.5 & 52.0 & 51.6 & 52.4 & 51.9 \\
\hline
\end{tabular}

（資料）厚生省公賩衛生局栄養課

表-4 植物油脂原料の品目別搾油状況

(単位: $1,000 t$ )

\begin{tabular}{|c|c|c|c|c|c|c|c|c|c|c|c|c|}
\hline & 品目年次 & 46 & 47 & 48 & 49 & 50 & 51 & 52 & 53 & 54 & 55 & 56 \\
\hline & なた䡈・からし & 22 & 15 & 12 & 9 & 7 & 6 & 5 & 5 & 1 & 1 & 2 \\
\hline 国 & 米视 か & 593 & 590 & 561 & 562 & 540 & 550 & 580 & 571 & 585 & 559 & 535 \\
\hline & 豆 & 0 & 0 & 0 & 0 & 1 & 0 & 0 & 0 & 3 & 3 & \\
\hline 産 & 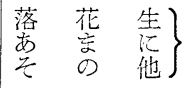 & 3 & 2 & 1 & 2 & 1 & 0 & 0 & 2 & 0 & 2 & \\
\hline & 計 & 618 & 607 & 574 & 573 & 549 & 556 & 585 & 578 & 589 & 565 & \\
\hline & 大 & $\begin{array}{l}(67.2) \\
2,521\end{array}$ & $\begin{array}{l}(66.6) \\
2,636\end{array}$ & $\begin{array}{l}(67.0) \\
2,739\end{array}$ & $\begin{array}{l}(69.1) \\
2,729\end{array}$ & $\begin{array}{l}(69.1) \\
2,619\end{array}$ & $\begin{array}{l}(68.8) \\
2,701\end{array}$ & $\begin{array}{l}(69.1) \\
2,878\end{array}$ & $\begin{array}{l}(70.6) \\
3,297\end{array}$ & $\begin{array}{l}(68.8) \\
3,401\end{array}$ & $\begin{array}{l}(69.1) \\
3,450\end{array}$ & $3,495^{*}$ \\
\hline & な放 & $\begin{array}{c}(10.9) \\
408\end{array}$ & $\begin{array}{c}(14.4) \\
568\end{array}$ & $\begin{array}{c}(16.8) \\
689\end{array}$ & $\begin{array}{c}(17.0) \\
672\end{array}$ & $\begin{array}{c}(18.5) \\
701\end{array}$ & $\begin{array}{c}(17.6) \\
692\end{array}$ & $\begin{array}{c}(18.5) \\
769\end{array}$ & $\begin{array}{c}(18.1) \\
843\end{array}$ & $\begin{array}{l}(21.8) \\
1,078\end{array}$ & $\begin{array}{l}(20.2) \\
1,007\end{array}$ & 1,187 \\
\hline & か & 9 & 10 & 6 & 7 & 10 & 8 & 7 & 9 & 1 & 2 & \\
\hline 輸 & 綿 & 266 & 189 & 152 & 134 & 107 & 92 & 93 & 92 & 74 & 78 & 73 \\
\hline & サフラワー & 32 & 72 & 36 & 32 & 21 & 13 & 14 & 21 & 19 & 24 & 20 \\
\hline & ご & 27 & 30 & 35 & 34 & 25 & 29 & 33 & 34 & 38 & 37 & 39 \\
\hline & とうもるこし & 49 & 56 & 60 & 62 & 60 & 76 & 100 & 113 & 128 & 140 & 146 \\
\hline & 落 花 生 & 0 & 0 & 1 & 0 & 0 & 0 & 0 & 0 & 0 & 0 & 0 \\
\hline & カ ボック & 35 & 30 & 22 & 20 & 16 & 16 & 10 & 5 & - & 0 & 0 \\
\hline & ひ亡わり & 43 & 26 & 5 & 1 & 0 & 0 & - & - & - & - & - \\
\hline & $=\quad 7^{\circ}$ & 123 & 128 & 132 & 87 & 89 & 110 & 98 & 91 & 54 & 67 & 72 \\
\hline 入 & パー ム 核 & 39 & 23 & 14 & 4 & 7 & 7 & 11 & 6 & 9 & 14 & 13 \\
\hline & あ ま に & 113 & 119 & 106 & 93 & 71 & 92 & 85 & 96 & 100 & 110 & 101 \\
\hline & ひま ま & 63 & 45 & 46 & 38 & 36 & 43 & 42 & 35 & 32 & 32 & 23 \\
\hline & そ の 他 & 24 & 25 & 47 & 34 & 27 & 45 & 25 & 26 & 12 & 30 & \\
\hline & 計 & 3,752 & 3,957 & 4,090 & 3,947 & 3,789 & 3,924 & 4,165 & 4,668 & 4,946 & 4,991 & \\
\hline 金 & 計 & 4,370 & 4,564 & 4,664 & 4,520 & 4,338 & 4,480 & 4,750 & 5,246 & 5,535 & 5,556 & 5,739 \\
\hline
\end{tabular}

注）（）は輸入原料に占的る割合 $(\%), *$ は翰入, 国産の合計 (資料) 農林水产省食品油脂課

表-5 配合飼料用植物油かすの需要

(単位: $1,000 t$ )

\begin{tabular}{|c|c|c|c|c|c|c|c|c|}
\hline $\begin{array}{lll}\text { 品目 } \quad \text { 年次 } \\
\end{array}$ & 48 & 49 & 50 & 51 & 52 & 53 & 54 & 55 \\
\hline 大 豆油 か す & $\begin{array}{l}(9.9) \\
1,799 \\
\end{array}$ & $\begin{array}{l}(9.9) \\
1,787\end{array}$ & $\begin{array}{l}(10.4) \\
1,707\end{array}$ & $\begin{array}{l}(10.3) \\
1,862\end{array}$ & $\begin{array}{l}(10.9) \\
2,129\end{array}$ & $\begin{array}{l}(11.3) \\
2,363\end{array}$ & $\begin{array}{l}(10.8) \\
2,477\end{array}$ & $\begin{array}{l}(11.2) \\
2,525\end{array}$ \\
\hline 米ぬか油かす & $\begin{array}{l}(1.8) \\
319\end{array}$ & $\begin{array}{l}(1.9) \\
349\end{array}$ & $\begin{array}{l}(1.9) \\
307\end{array}$ & $\begin{array}{l}(1.7) \\
318\end{array}$ & $\begin{array}{l}(1.7) \\
327\end{array}$ & $\begin{array}{l}(1.4) \\
296\end{array}$ & $\begin{array}{l}(1.4) \\
310\end{array}$ & $\begin{array}{l}(1.3) \\
293\end{array}$ \\
\hline なた漦油かす & $\begin{array}{c}(0.5) \\
90\end{array}$ & $\begin{array}{c}(0.7) \\
133\end{array}$ & $\begin{array}{c}0.8) \\
138\end{array}$ & $\begin{array}{l}(0.7) \\
124\end{array}$ & $\begin{array}{c}\left(\begin{array}{c}0.8 \\
168\end{array}\right) \\
\end{array}$ & $\begin{array}{l}(0.7) \\
148\end{array}$ & $\begin{array}{l}\left(\begin{array}{c}0.9) \\
213\end{array}\right) \\
\end{array}$ & $\left(\begin{array}{l}1.1) \\
253\end{array}\right.$ \\
\hline その他植物 油かす & $\begin{array}{l}\left(\begin{array}{l}3.1) \\
562\end{array}\right)\end{array}$ & $\begin{array}{l}(2.4) \\
429\end{array}$ & $\left(\begin{array}{l}1.9) \\
303\end{array}\right.$ & $\begin{array}{l}(2.0) \\
355\end{array}$ & $\begin{array}{l}(1.3) \\
250\end{array}$ & $\left(\begin{array}{l}1.0) \\
203\end{array}\right.$ & $\begin{array}{c}(0.8) \\
180\end{array}$ & $\begin{array}{l}(0.9) \\
193\end{array}$ \\
\hline 配 合 飼 料 計 & 18,113 & 17,998 & 16,272 & 18,094 & 19,527 & 20,832 & 22,489 & 22,471 \\
\hline 対 前 年 比 & 107.5 & 99.4 & 90.7 & 110.7 & 107.9 & 106.7 & 108.0 & 99.9 \\
\hline
\end{tabular}

注）（）内は配合飼料に占める割合（\%) (資料) 日本飼料協会「飼料日報」 


\section{2 製油技術}

製油技術の最近の進歩や動向，ならびに油脂原料の品

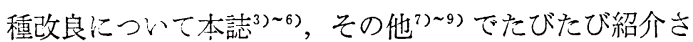
れ特集された。食品衛生, 公害防止のための熱媒転換, 環境污染防止一の対応として大気污染, 廃水処理, 騒音 対策にも製油業界として取り組んできてほぼ目的定達し た。

\section{1 省エネルギー}

昭和 48 年の第 1 次石油ショックを契機化エネル゙ー 利用の効率化空計る努力が行政とともに各産業界でなさ れてきた。鉄鋼を初为とする主要業種のエネルギー原単 位は 48 年度に比べて 54 年度には 10 20\%, 石油原単 位で 15 25\% 低減された ${ }^{10)}$ 。省エネルギーの技術対策 の第 1 段階は「余分に与えすぎていたり逃がしていたエ ネルギーを減ら方」管理強化，第 2 段階は「設備改善や 廃エネルギー回収」, 第 3 段階は「プロセスの変更や工 程短縮, 連続化などプラント規模での改善」とされてい $3^{10)}$ 。

製油における省エネルギー活動は本誌に詳しく紹介さ れている。井田 ${ }^{11}$ の工場実例報告によると，その工場の 第 1 段階の目標々して「節約運動と意識の徽底」を掲 げ，熱エネルギー $10 \%$ 節減をめざし，約 1 年間で 10.2 以の実績を得た。第 2 段階は全工場の熱エネルギーの 5 割強を消費している製油工程（摍油及び精製）を対象と し，省エネルギー推進組織を基に外部コンサルタントも 導入して取り組んだ。活動のプロセスは，製油各工程を 細目にわたって分解し，それらの機能を満たすのに必要 なエネルギー理論量と実際量との差の大きさ, 及びその 実現可能性を必要に応じて予備テストも実施して評価 し，優先度をつけ，構想案ごとに投資額と節減額を算出 し総合案を作成した。節減目標 $25 \%$ に対し活動期間 8 か月で $29.3 \%$ の実績を得た。日本油脂協会でも省エネ ルギープログラムのマニュアル化が進められた。

筆者も工場において省エネルギー活動に取り組んだ。 省エネルギーを工場における総合的なコストダウンとい ら観点から位置づけるとともに, 品質保証活動も折りこ んで, 80 年代に備えた工場ら゙くりのプロセスとした。 推進体制や改善事例の詳細についてはかつて発表する機 会を得だ2 。

アメリカにお沙る省エネルギー活動実施例を Ander= son Clayton Foods の Brooks が述べている ${ }^{13)}$ 。連邦政 府は 1975 年工業部門の 10 業種を省エネルギー重点と して指定したが，食品は 6 位倍位置し，年 2 回のエネル ギー消費量の報告を義務づけられ，1980 年 1 月 1 日ま でに $14 \%$ のエネルボー削減を要請された。ショートニ ング及びクッキングオイル工業は製品ポンド当たり平均 2,400 BTU を消費していることが明らかにされた。工
程の分析を行った結果(1)ボイラー効率, (2)タンクや装置 の保温, (3)設備管理プログラム, (4)水素発生機の移設, (5)工程改良の 5 項目での改善で 35〜40\% のエネルギー 節減が可能であることがわかったが, 省エネルギーのた 内の投資, 操作員の習慣を変えさせることの難しさも同 時に述べている。

製油装置上の省エネルギーについて De Smet の Athanassiadis $^{14)}$ は, (1)電気及び熱エネルギ一節減のた め製品や媒体回路の単純化, (2)熱の回収, (3)真空装置の 蒸気使用量低減, 脱臭吹き込み蒸気の効率化, (4)装置や プラインからの放熱量低減, とくに高温部の保温, (5)ボ パイイラー效率向上と凝縮回収の 5 項目を挙げ，(1) (3) が製油という特定分野のテクノロジーいかんによるとし た。連続式脱酸一脱色ライフについて, 高温の脱色沪過油 を中間タンクに大れ，脱酸を施す原油と熱交換すること， フィルタープレスからケーキをブローアウトしたあとの 蒸気を利用して温水をつくり脱酸洗浄に用いること， 1 つの真空系を洗浄後の乾燥（ドライヤー）及び脱色缶に 用いることで $\mathrm{t}$ 当たり蒸気量が $183 \mathrm{~kg}$ から $106 \mathrm{~kg}$ に低 減され, 熱交換器 38 万 BF の設備費に対し 5 万 $\mathrm{t} / \mathrm{y}$ の 生産で 110 万 $\mathrm{BF}$ の利益になるとしている(BF : ベルギ ーフラン)。

連続式脱酸一脱色, ウィンター（ひまわり及びとうも ろこし油)，脱臭ラインについて，ウィンター沪過した 低温の油と高温の脱色沪過油（ひまわりもしくはとうも ろこし油）との熱交換， $75^{\circ} \mathrm{C}$ に加温したウィンター沪 過油を $140^{\circ} \mathrm{C}$ に予熱後脱臭缶へ導入乙, 高温の脱臭済み 排出油との熱交換による加熱と脱気，その後熱媒や高圧 蒸気などによる加熱後脱臭といら方式で $\mathrm{t}$ 当たり $140 \mathrm{~kg}$ の蒸気が低減される。これは熱交換器 2 基の 78 万 $\mathrm{BF}$ の設備費に対し 5 万 $\mathrm{t} / \mathrm{y}$ の生産で 210 万 BF の利益にな るとしている。

連続式スチームリファイニング法でほ, $255^{\circ} \mathrm{C}$ の脱臭 油を $70^{\circ} \mathrm{C}$ に冷却する閒澊入原油を $50^{\circ} \mathrm{C}$ から $210^{\circ} \mathrm{C}$ まで工程に応じて順次に熱交換し加熱することにより $30 \%$ の熱エネルギーが節約される。そのらえ蒸気はプ ラントのスタートアップ時以外必要はなく冷却水も要し ない。

半連続式脱臭缶について De Smet は熱交換の異なる 2 方式を採用している。1つは仕込み油をプレート熱交 換器で予熱後コイル熱交換器で加熱-脱気するもので高 温の脱臭油と熱交換される。これにより油を $50^{\circ} \mathrm{C}$ から $250^{\circ} \mathrm{C}$ 亿昇温させる熱エネルギーの $70 \%$ が回収される。 この方式は数日間同一の油を処理する場合に用いるもの である。もう1つの方式は油種切り換えが多い場合に適 するもので，熱媒としてグリセリンなどが用いられる。

\section{$2 \cdot 2$ 自動化}

製油プロセスの自動化は過去 20 年間に次第に装備さ 
れてきた。Duff ${ }^{15)}$ は自動化の目的ないし効果を，(1)製 造費の低減, (2)品質の安全化と向上, (3)人為的エラーに よるロスをなくし高収率を得る，(4)溶剂や水素を用いる プラントでの安全性の確保に集約し, 製油各工程の自動 化の実施を詳細に例示した。製油プロセスにおけるコン ピューター管理は石油精製など他工業に比べて遅かった が，これは化学分析を電気シグナルに変える変換器がな かったこと ${ }^{16)}$ ，また製油のプラント規模が他工業に比べ て小さかったためコンピューター管理コストが高くつい ていたこと㐨による。コンピューター技術の急速な進歩 及び資本コストの低下により経済的なバリヤーは次第に 取り除かれてきた。

最近のプロセス自動化の特徵を従来の制御方法と対比 し 表-6 に示すが，プロセスコンピューターの導入と集 中制御方式の進展が大きな特徵といえよう。集中制御は

表-6 最近の自動化方法と従来の制御方法の特徵

\begin{tabular}{|c|c|c|}
\hline & 最近の自動化方法 & 従来の制御方法 \\
\hline 設備面 & 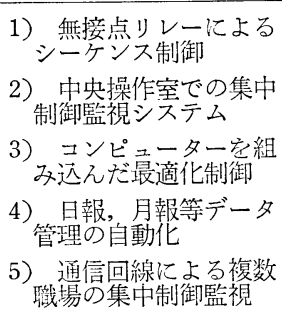 & 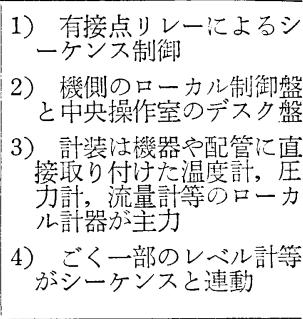 \\
\hline 操作 & $\begin{array}{l}\text { 1) 定着管理からパトロ } \\
\text { ール移行 } \\
\text { 2) 部分的にオンライン } \\
\text { 計測機器を使い工程管 } \\
\text { 理が中心 }\end{array}$ & 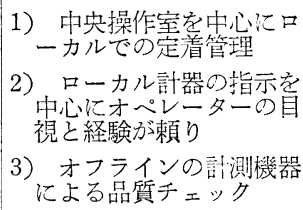 \\
\hline
\end{tabular}

脱酸, 脱色, 沪過, 脱臭, エステル交換, 油の移送, 配 合，アルカリフーツ分解の連続プラントに装備されてき $た^{15)}$ 。分析機器の自動化も進み, 従来のオフライン方式 からプラントに組み込まれオンライン工程管理が一部導 入できるようになってきた。この場合工程管理上は精確 だが時間を要する方法よりラフだが迅速な方法がベター である15)。

Bitner $\check{~}^{16)}$ は大豆脱ガム油を出発原料とする脱酸，脱 色，水添，脱臭の 4 工程の一貫ミニ装置を組み立てた。 脱酸は Zenith 法に類似した方法を用い, 脱色は白土 1 \%として連続沪過を行う。水添は赤外線吸収（トランス 酸含量), 屈折率, 反応温度, かきまぜ速度及び水素流 量をモニタリングしながら IV 85〜90 に連続水添する が, 水添油の自動 GC 分析は研究中である。脱臭は水蒸 気流量, 温度及び真空度を変換器によってモニタリング するが，においを示す装置がないため脱臭完了を感知す ることが他の工程と比べて最も困難であった。各工程の
最適化を図ること及び新しい変換器の開発が今後の課題 であるが，実使用の可能性については，原油あるいはと くに品質の劣る原油の精製条件の予測や品質評価汇用い ることができるとしている。

今後の自動化の方向については，コンピューターを中 心とするハード構成は基本的に変わらないと思われる が，より機能的になりマン・マシン性の向上が計られよ う。また分析機器, センサーの開発がなされオンライン管 理が進められ,プロセス全体のバランスを見ながら品質, 歩止まり上の最適制御が計れるようになるであろう。と くに抽出ミールの残油分, ヘキサンのホールドアップ量, ミールのタンパク質含量, 水添油の屈折率, 遊離脂肪酸 含量, SFI などのオンライン機器の開発が望まれる ${ }^{17)}$ 。

\section{3 アンモニア脱酸}

アンモニア脱酸はすでに約 50 年前に提案されたが, 環境污染の面から Pardun ${ }^{18)}$ が再び見直している。すな わら西ドイツで 1973 年当時約 160 万 $\mathrm{t}$ の植物原油が処 理されたが，原油中の遊離脂肪酸含量 $19 \%$, 脱酸に $10 \%$ 過剩の水酸化ナトリウム使用として計算すると, アルカ リフーツの分解に約 $3,000 \mathrm{t}$ の硫酸を消費し, 生成する 硫酸ナトリウム約 $4,500 \mathrm{t}$ の処理が必要となる。アンモ ニア脱酸はすべての種類の原油に適用でき，アンニニア の再使用が可能で排水に硫酸塩が含まれないといら利点 がある。脱酸条件を検討した結果 Pardun はつぎの 2 方 法を提言した：(1水和脱ガム油を $50 \%$ 過剩のアンモニ アで処理後遠心分離してアンモニアと 20〜30\% の の中性 油を含む脂肪酸とを回収する。脱酸油は必要に忘じて水 酸化ナトリウムの後処理後水洗, 脱色, 脱息する。(2)原 油にクエン酸もしくはギ酸添加後アンモニア処理し遠心 分離する。フーツに蒸気を吹き込んでアンモニア及び脂 肪酸含量の高いレシチンを得る。脱酸油は水洗, 脱色, 脱臭する。これらの方法は水酸化ナトリウム脱酸の場合 と同じ歩止まりが得られている。

\section{4 膜分離技術の製油プロセスへの応用}

各種の機能性高分子膜について工業上，医療上多方面

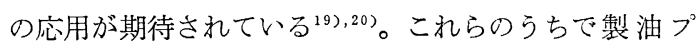
ロセスに応用されるものは限外沪過膜で, 膜の構造, 沪 過の理論, 装置について橋野 ${ }^{21}$ が解説している。

ユニリーバー社は, リン脂質を含む原油ミセラをアク リロニトリルなどの重合膜に圧力下透過させリン脂質を 除去する方法を開発した ${ }^{22}$ 。従来のリン酸添加脱ガムーア ルカリ脱酸では加熱蒸気の使用，アルカリによる約 $20 \%$ もしくはそれ以上のリン脂質の破壊，中性油の約 $1 \%$ が ソーダ油さいとともに失われる, 排水の処理等の問題を 有する。実施例によると粗製大豆油ミセラをジメチルポ リシロキサンエラストマーの管状膜中 $20^{\circ} \mathrm{C} て ゙$ 再循環さ せ, 透過油中のリン濃度は $2 \mathrm{ppm}$ 末満, ロビボンド (2 in.) 色度は粗製油 $70 \mathrm{Y}+8 \mathrm{R}$ に対し沪過油 $40 \mathrm{Y}+$ 
5R となった。またこの方法は重合油が形成されたフラ イ油から部分的に三量体以上のオリゴマーを分離でき る。同発明者法またリン $990 \mathrm{ppm}$ を含みロビボンド (2 in.) 色度 $70 \mathrm{Y}+7 \mathrm{R}+0.2 \mathrm{~B}$ の粗製大豆油ミ七ラを限外 汇過, シリカゲルカラム処理，脱臭の組み合わせで官能 的にも満足できる製品油を得ている ${ }^{23)}$ 。これらはミセラ を沪過する方法であるが溶剤によりリン脂質のミセルが 形成され，リン脂質が透過しなくなることを利用したも のである。一方鈴木ら ${ }^{24}$ は溶剂䘮使用出す膜処理してり ン脂質以外に鉄，銅，カルシウム，マグネシウムなどの 金属も分離する方法を開示した。

膜分離技術注以上の上うに，省エネルギー，環境污染 防止，歩止まり向上などの利点孛有し今後期待される技 術である。膜の材質, 構造, 構成の開発がさらに進的ら れると脱ガム以外脱色, 脱万ら, スチームリファイニ ング法などに応用がひらけてくるであろう。膜の寿命, 洗浄方法, 連続運転上のエンジニアリング, コスト低減 などが今後の課題とされている。

\section{5 超臨界二酸化炭素抽出}

通常行われているへキサン抽出に代わって超臨界二酸 化炭素抽出がパイロット規模で試験された ${ }^{25)}$ 。二酸化炭 素に限らず各種のガス体ないし液体が超臨界状態を呈 し，この方法の原理はすでに 40 年以上前に発表された。 それらの性質, 抽出操作への応用について播磨 ${ }^{26)}$ が解説 している。Krupp 社によると，製油関連ではなたね油， 大豆油, パーム油の精製, 分別, 牛脂の精製 (不けん化 物の分離), 大豆粗レシチンから純レシチンの抽出, と うもろこし油の精製，トコフェロールやステロールの製 取, 古い油の精製, 分別に利用できるという ${ }^{25)}$ 。

Stahl ${ }^{27}$ は 300 bar の圧力下 $40 \sim 50^{\circ} \mathrm{C}$ での 2 段抽 出で，なた㱛，大豆，ひまわりともへキサン抽出に匹敵 する抽出歩止まりを得た。二酸化炭素抽出は条件により 抽出油の品質を変えることができ, 残留溶媒の盧がない という利点のほか, 二酸化炭素法無尽蔵に調達できる利 点がある27)。

西ドイツを中心とする以上の研究のほか, 最近はアメ リカでも大豆などからの抽出実験が行われ学会発表がな されている(1982年 3 月のニューオルリンズにおける学 会,及び 5 月のトロントにおける学会)。前者の学会での Friedrich と List $^{28}$ によるつフリプリントによると, 超臨 界二酸化炭素抽出による大豆油はへキサン抽出油に比べ て同等の抽出歩止まりを得たうえりン含量が約 $1 / 10$ の $60 \mathrm{ppm}$ と低く, 従って精製ロスも低い。また Mounts ${ }^{29}$ による大豆ととうもろこしはい芽の抽出かすの品質評価 で，とうもろこしではへキサン抽出に勝った。今後さら にデータの発表が待たれるところである。

\section{おわりに}

昭和 48 年の天候異変と米国大豆輸出規制, 引き続き 石油ショック, 当時 800 億円といわれた製油業界末曽有 の欠損, 200 海里漁業水域問題, 第 2 次石油ショック, そして前年来の畜産不振とミール暴落, 円安と, 製油業 界の屋台骨を摇るがす出来事がこの 10 年間にも絶える ことがなかった。現今の日本経済がかかえる貿易摩擦問 題も製油業界一何らかの影響を及ぼすであろら。

本稿でふこれまでの時代背景から省エネルギー及び自 動化を中心に，そして幾つかの技術にスポットを当てて 今後の展望を試みた。全ぼらを示すには至らなかったが 少しでも参考になれば幸いである。

（昭和 57 年 6 月 15 日受琹）

\section{文献}

1) 東森 宏, 油化学, 28, 656 (1979)

2) 油脂, 35 (1) 26 (1982)

3）竹下安日児, 油化学, 27, 13 (1978)

4) 浜島守男, 油化学, 28, 662 (1979)

5) 松原繁左右, 油化学, 28,670 (1979)

6) 桂 英二, 油化学, 28, 709 (1979)

7) J. Am. Oil Chem. Soc., 53 (6), (1976)

8) J. Am. Oil Chem. Soc., 55 (11), (1978)

9) T.L. Mounts, J. Am. Oil. Chem. Soc., 58, 51 A (1981)

10）週刊ダイヤモンド別册，新・省エネルギー読本，(1981), p. 14 , p. 18

11) 井田 暿, 油化学, 30, 343 (1981)

12）（財）食品産業センター, 食品工業におけるエネルギー 節減事例 $(55 / 3)(1980)$, p. 25

13) B.F. Brooks, J. Am. Oil Chem. Soc., 55, 772 (1978)

14) A. Athanassiadis, Fette, Seifen, Anstrichm., 82, 219 (1980)

15) A.J. Duff, J. Am. Oil Chem. Soc., 53, 370 (1976)

16) E.D. Bitner, J.M. Snyder, J.O. Erunst, H.J. Dut= ton, Fette, Seifen, Anstrichm., 79, 483 (1977)

17) N.H. Witte, J. Am. Oil Chem. Soc., 57, 854 A (1980)

18) H. Pardun, Fette, Seifen, Anstrichm., 81, 297 (1979)

19）（株）シーエムシー R\&D レポート，No. 18 , 機能性 膜の最先端技術（昭 56）

20）渡辺敦夫, 大谷敏郎, 食品工業，23 (8), 20（4下-1980）

21）橋野康雄, 食品機械装置, 9 (1977)

22）アヒンチヤ・クマー・ゼン・グプタ,公開特許, 昭 $50-153,010$

23） アヒンチヤ・クマー・ゼン・グプタ,公開特許，昭52-84,206

24）鈴木清次, 佐藤成一, 宮川久雄, 公開特許, 昭57-5793

25） Fried Krupp GmbH 技術資料 (1981. 3. 31)

26）播磨幹夫, 食品工業, 25 (6), 47 (3下-1982)

27) E. Stahl, E. Schütz, H.K. Mangold, J. Agric. Food Chem., 28, 1153 (1980)

28) J.P. Friedrich, G.R. List, 31 th Oilseed Processing Clinic でのプリプリント

29） T.L. Mounts, 同上 